\title{
Author Correction: Mapping histone modifications in low cell number and single cells using antibody- guided chromatin tagmentation (ACT-seq)
}

Benjamin Carter (1), Wai Lim Ku (1), Jee Youn Kang, Gangqing Hu, Jonathan Perrie, Qingsong Tang \& Keji Zhao (B)

Correction to: Nature Communications https://doi.org/10.1038/s41467-019-11559-1, published online 20 August 2019.

The original version of the Supplementary Data associated with this article duplicated Supplementary Data 1 for both Supplementary Data 1 and Supplementary Data 2. The correct file can be found here: Supplementary Data 2.

This has now been corrected in the HTML version.

Published online: 01 September 2020

Open Access This article is licensed under a Creative Commons Attribution 4.0 International License, which permits use, sharing, adaptation, distribution and reproduction in any medium or format, as long as you give appropriate credit to the original author(s) and the source, provide a link to the Creative Commons license,
and indicate if changes were made. The images or other third party material in this article are included in the article's Creative Commons license, unless indicated otherwise in a credit line to the material. If material is not included in the article's Creative Commons license and your intended use is not permitted by statutory regulation or exceeds the permitted use, you will need to obtain permission directly from the copyright holder. To view a copy of this license, visit http://creativecommons.org/licenses/by/4.0/.

(๑) This is a U.S. Government work and not under copyright protection in the US; foreign copyright protection may apply 2020 